\title{
Retraction: profiling the different needs and expectations of patients for population-based medicine: a case study using segmentation analysis
}

Federico Lega ${ }^{{ }^{*}}$ and Alessandro Mengoni ${ }^{2}$

\section{Retraction}

This article has been retracted [1] by the authors because they do not have ownership of the data presented, which was originally collected by the Laboratorio Management e Sanità of Scuola Superiore Sant'Anna. In addition, the data presented in this article has previously been used for a publication in the Italian journal "Mercati e Competitività" [2]. The authors apologise to the readers, the publisher and the authors of the Italian publication for any inconvenience caused.

\section{Author details}

${ }^{1}$ Department of Policy Analysis and Public Management, Cergas and Area PMP SDA Bocconi, Bocconi University, Via Rontgen 1, Milan 20136, Italy. ${ }^{2}$ ASUR Marche, Via caduti del lavoro 40, Ancona 60100, Italy.

Received: 16 May 2013 Accepted: 16 May 2013

Published: 20 May 2013

\section{References}

1. Lega F, Mengoni A: Profiling the different needs and expectations of patients for population-based medicine: a case study using segmentation analysis. BMC Health Serv Res 2012, 12:473.

2. Mengoni A, Murante AM, Nuti S, Tedeschi P: Segmentazione e Marketing per la sanità pubblica. Mercati e Competitività 2010, 1:119-139.

\footnotetext{
* Correspondence: federico.lega@unibocconi.it

${ }^{1}$ Department of Policy Analysis and Public Management, Cergas and Area PMP SDA Bocconi, Bocconi University, Via Rontgen 1, Milan 20136, Italy

Full list of author information is available at the end of the article
}

Submit your next manuscript to BioMed Central and take full advantage of:

- Convenient online submission

- Thorough peer review

- No space constraints or color figure charges

- Immediate publication on acceptance

- Inclusion in PubMed, CAS, Scopus and Google Scholar

- Research which is freely available for redistribution 